\title{
Helicobacter species are associated with possible increase in risk of biliary lithiasis and benign biliary diseases Manoj Pandey
}

Address: Department of Surgical Oncology, Institute of Medical Sciences, Banaras Hindu University, Varanasi 221005 , India

Email: Manoj Pandey - manojpandey@vsnl.com

Published: 20 August 2007

World Journal of Surgical Oncology 2007, 5:94 doi:10.1 186/1477-78/9-5-94

This article is available from: http://www.wjso.com/content/5/l/94

(C) 2007 Pandey; licensee BioMed Central Ltd.

This is an Open Access article distributed under the terms of the Creative Commons Attribution License (http://creativecommons.org/licenses/by/2.0), which permits unrestricted use, distribution, and reproduction in any medium, provided the original work is properly cited.

\begin{abstract}
Background: Hepato-biliary tract lithiasis is common and present either as pain or as asymptomatic on abdominal ultrasonography for other causes. Although the DNA of Helicobacter species are identified in the gallbladder bile, tissue or stones analyzed from these cases, still a causal relationship could not be established due to different results from different geographical parts.

Methods: A detailed search of pubmed and pubmedcentral was carried out with key words Helicobacter and gallbladder, gallstones, hepaticolithiasis, cholelithiasis and choledocholithiasis, benign biliary diseases, liver diseases. The data was entered in a data base and meta analysis was carried out. The analysis was carried out using odds ratio and a fixed effect model, $95 \%$ confidence intervals for odds ratio was calculated. Chi square test for heterogeneity was employed. The overall effect was calculated using $Z$ test.

Results: $A$ total of 12 articles were identified. One study used IgG for diagnosis while others used the PCR for Ure A gene, 16 S RNA or Cag A genes. A couple of studies used culture or histopathology besides the PCR. The cumulative results show a higher association of Helicobacter with chronic liver diseases (30.48\%), and stone diseases (42.96\%)(OR $1.7795 \% \mathrm{Cl}$ I.2-2.58; Z = 2.94, $p=0.003$ ), the effect of each could not be identified as it was difficult to isolate the effect of helicobacter due to mixing of cases in each study.

Conclusion: The results of present meta analysis shows that there is a slight higher risk of cholelithiasis and benign liver disease (OR I.77), however due to inherent inability to isolate the effect of stone disease from that of other benign lesions it is not possible to say for sure that Helicobacter has a casual relationship with benign biliary disease or stone disease or both.
\end{abstract}

\section{Background}

The benign diseases of the hepatobiliary system and the stone disease is one of the common problems encountered in some parts of the world. Some of the causes of biliary lithiasis are known while others are still being debated. Infection of the biliary tract has also been suspected to lead to stone formation, which is also been described as tomb of a bacteria. There is an increasing con- cern that preexisting untreated stone disease could lead to malignancy in long run [1].

Although Helicobacter species are identified in the bile, tissue and stones of the patients with stone disease and the benign biliary diseases, due to differing results that have been obtained from different geographical regions no causative relationship could be established till date [2] 
This article systematically reviews the evidence available on the role of Helicobacter species in benign diseases and biliary tract lithiasis and presents a meta analysis of results.

\section{Methods}

A detailed pubmed search was made using key words 'hepatobiliary', 'biliary','gallbladder' and 'neoplasia', or 'tumor', stone, lithiasis, cholelithiasis, hepaticolithiasis, choledocholithiasis, gallstone and Helicobacter. The search was then limited to humans. The articles were carefully read and were classified into observational or case-control study type. The data on method of detection, number of positive cases for Helicobacter in subjects and controls and the type of organisms identified were extracted and entered in the database prepared for the purpose. Total samples analyzed in the study were taken into account irrespective of methods of detection used. If a study used three methods of detection, the sample of all the three methods was summed to get total number and number of positive cases. No attempt was made to study the effect of method of detection in the present analysis. Meta analysis was carried out for the above data from the case control studies despite their heterogeneity with the goal that if an association is observed in this meta analysis this will help in designing further studies and will also help in understanding what kind of studies are exactly required.

Meta analysis was carried out using odds ratio and a fixed effect model, 95\% confidence intervals for odds ratio was calculated. Chi square test for heterogeneity was employed. The overall effect was calculated using Z test.

\section{Results}

The abstract of each article was screened by author and a total of 12 articles that were found to be relevant were identified [3-14]. These articles form the basis of the present review. The salient features of these articles on methodology, diseases studied and results are summarized in table 1.

Of the case control studies, 8 studies were purely on gallstone disease [5-7,10-14] (table 1; figure 1), While 4 others examined the population with stones beside either other chronic diseases or malignancies of biliary tract $[3,4,8,9]$. The cumulative sample size of these 12 studies was 797 of which $322(40.4 \%)$ were positive for Helicobacter species. The positivity in the controls was $145 / 615$ (23.5\%). One study each used UreA gene analysis and 26 kDa antigen for identification of Helicobacter, another used CagA, while rest used 16s rRNA or DNA based PCR. Positivity in biliary epithelium was much higher 40$62.5 \%[3,5]$ compared to that in bile. Seven of these identified $H$. pylori, one study identified Campylobacter sp while two identified $H$. bilis, and rest identified Helicobacter $s p$.
The positivity rate among controls was $23.5 \%$. Of the 9 studies where the sample size of lithiasis patients was available 272/633 samples from cases and 118/268 samples from controls were positive. The cumulative odds ratio of these studies was 1.77 (95\% CI 1.21-2.58) ( $\mathrm{Z}=$ $2.94, \mathrm{p}=0.003)$. Three studies looked at the patients with benign hepato-biliary diseases. Addition of these studies raised the sample size to 797 cases and 615 controls. The odds ratio after addition of these studies increased to 2.46 (95\% CI 1.8-3.36; I2 76\%, $Z=5.68$ ) (figure 2). It was found that the study of Figura et al., [13] used Cag A in bile and gallstones for detection of $H$ pylori and contributed nearly $1 / 3$ of the weight in the overall effect due to its large sample size. Exclusion of this study from the estimation lead to Odds of 2.16 [95\% CI 1.35-3.45] in stone disease with $\mathrm{I}^{2}$ of $65.3 \% \mathrm{Z}$ value of $3.22(\mathrm{p}=0.001)$ and odds of 3.05 [95\% CI 2.13-4.36] in benign diseases including stones with $\mathrm{I}^{2}$ of $71.7 \%$ and $\mathrm{Z}$ value of 6.08 ( $\left.\mathrm{p}<0.0001\right)$. Thus increase in odds was observed for both groups by exclusion of this study (Figure 3 and 4 ).

\section{Discussion}

The genus of Helicobacter has expanded to include number of species [15]. The most studied among these is Helicobacter pylori (H. Pylori), that colonizes the stomach and has been found to be associated with benign diseases like gastritis [16], and peptic ulcer disease [17]. H. pylori is a spiral highly motile microaerophillic organism, uniquely adopted to survive by burrowing into the mucous layer when it is well protected from the host environment.

Some other species like $H$. hepaticus and $H$. bilis have been shown to infect the liver and the presence of them has been associated with hepatitis and hepatobiliary neoplasms $[1,15,18,19]$.

The complete genomic sequence of $H$. Pylori and $H$. hepaticus is now known. With the identification of $H$. pylori the paradigm for the management of peptic ulcer, chronic gastritis, MALT lymphoma and gastric adenocarcinoma has undergone paradigm shift $[20,21]$. The $H$ pylori infection is now also been implicated in diverse conditions like coronary artery disease, autoimmune thrombocytopenia, skin diseases, and growth retardation in children [22-25].

The Helicobacter sp have been reported to survive in bile juice and that has prompted people to think "could this bacterial colonization of bile be responsible for hepatobiliary disease" ? Helicobacter species has been identified in bile juice of patients with cholelithiasis, primary sclerosing cholangitis and primary biliary cirrhosis $[26,27,4,28,29]$.

It is also proposed that Helicobacter may also promote the risk of stone formation by acting as a foreign body to form 
Table I: Characteristics of case control studies on Helicobacter sp in benign hepatobiliary diseases and stone diseases.

\begin{tabular}{|c|c|c|c|c|c|c|}
\hline Reference and year & $\begin{array}{l}\text { Method of } \\
\text { detection }\end{array}$ & Specimen & Disease & $\begin{array}{l}\text { Helicobacter in } \\
\text { subjects } n / N\end{array}$ & $\begin{array}{l}\text { Helicobacter in } \\
\text { controls } n / N\end{array}$ & $\begin{array}{l}\text { Organism } \\
\text { identified }\end{array}$ \\
\hline Myung et al 2000 [3] & $\begin{array}{l}\text { PCR (UreA) (26 kDa } \\
\mathrm{Ag})\end{array}$ & $\begin{array}{l}\text { Intrahepatic Bile, } \\
\text { biliary duct tissue, } \\
\text { gallbladder }\end{array}$ & Hepatobiliary diseases & $\begin{array}{l}\text { 4/43 ureA } \\
5 / 4326 \mathrm{kDa}\end{array}$ & $\begin{array}{c}0 / 8 \\
0 / 23\end{array}$ & H. Pylori \\
\hline Nilsson et al 2000 [4] & PCR (16s rRNA) & Liver & $\begin{array}{l}\text { PSC } \\
\text { PBC }\end{array}$ & $\begin{array}{l}9 / 12 \\
11 / 12\end{array}$ & $\begin{array}{l}\text { 0/10 control } \\
\text { I/13 NCLC }\end{array}$ & H. Sp. \\
\hline Harada et al 200I [5] & PCR (I6s rRNA) & Bile, biliary epithelium & Intrahepatic calculi & $\begin{array}{c}3 / 14 \text { bile } \\
5 / 8 \text { biliary epithelium }\end{array}$ & $\begin{array}{l}0 / 9 \\
0 / 7\end{array}$ & Campylobacter sp. \\
\hline Leong et al 200I [6] & PCR (I6s rRNA) & Bile & $\begin{array}{l}\text { CBD stone } \\
\text { Cholangitis }\end{array}$ & $4 / 25$ & $0 / 4$ & H. Sp. \\
\hline $\begin{array}{l}\text { Presser Silva et al } \\
2003 \text { [7] }\end{array}$ & $\begin{array}{l}\text { Culture PCR (16s } \\
\text { rRNA) }\end{array}$ & $\begin{array}{l}\text { Bile } \\
\text { Gallbladder tissue }\end{array}$ & Cholelithiasis & $\begin{array}{l}20 / 64 \text { culture } \\
28 / 51 \text { histology } \\
24 / 56 \text { bile }\end{array}$ & $2 / 18$ & H pylori \\
\hline $\begin{array}{l}\text { Chen W et al } 2003 \\
\text { [8] }\end{array}$ & PCR & Gallbladder & Gall stones & $\begin{array}{l}29 / 60 \text { symptomatic } \\
6 / 10 \text { asymptomatic }\end{array}$ & $15 / 37$ & Helicobacter pylori \\
\hline $\begin{array}{l}\text { Vorojova T et al } 2006 \\
\text { [9] }\end{array}$ & $\lg$ Elisa & Serum & Chronic liver disease & $\begin{array}{l}13 / 35 \\
7 / 32 \\
1 / 27\end{array}$ & $\begin{array}{c}4 / 81 ; 0 / 16 \\
7 / 84 ; 0 / 6 \\
12 / 89 ; 3 / 17\end{array}$ & $\begin{array}{l}\text { H. hepaticus } \\
\text { H. bilis } \\
\text { H. pullorum }\end{array}$ \\
\hline Abayli et al 2005 [10] & $\begin{array}{l}\text { I6s rRNA } \\
\text { PCR } \\
\text { HPE }\end{array}$ & GB stone & Cholesterol stones & $7 / 77$ & $6 / 20$ & H pylori \\
\hline $\begin{array}{l}\text { Farshad Sh et al } 2004 \\
\text { [II] }\end{array}$ & 16s RNA & Stones Bile & Gall stones & $\begin{array}{l}6 / 33 \text { stones } \\
4 / 33 \text { bile }\end{array}$ & $0 / 40$ & $\begin{array}{l}H \text { pylori } \\
H \text { spp }\end{array}$ \\
\hline Bulajic et al 2002 [12] & ureA gene PCR & Bile & $\begin{array}{l}\text { Biliary lithiasis } \\
\text { cholengitis }\end{array}$ & $\begin{array}{l}\text { 26/48 stone } \\
9 / 17 \text { cholangitis }\end{array}$ & $\mathrm{I} / 7$ & H Pylori \\
\hline Figura et al 1998 [13] & CagA & Bile & gallstones & $92 / 112$ & $90 / 112$ & H. pylori \\
\hline $\begin{array}{l}\text { Matsukura et al } 2002 \\
\text { [14] }\end{array}$ & PCR I6s rRNA & Bile & $\begin{array}{l}\text { Biliary tract cancer } \\
\text { Gallstones }\end{array}$ & $\begin{array}{l}24 / 29 \text { malignant } 18 / 42 \\
\text { stone }\end{array}$ & $4 / 14$ & $H$ bilis \\
\hline
\end{tabular}

Chr. - chronic; CaGB - gallbladder cancer; CC - cholangiocarcinoma; HCC - hepatocellular carcinoma

PSC - Primary sclerosing cholangitis; PBC - primary biliary cirrhosis; CBD - common bile duct; GB - gallbladder

a

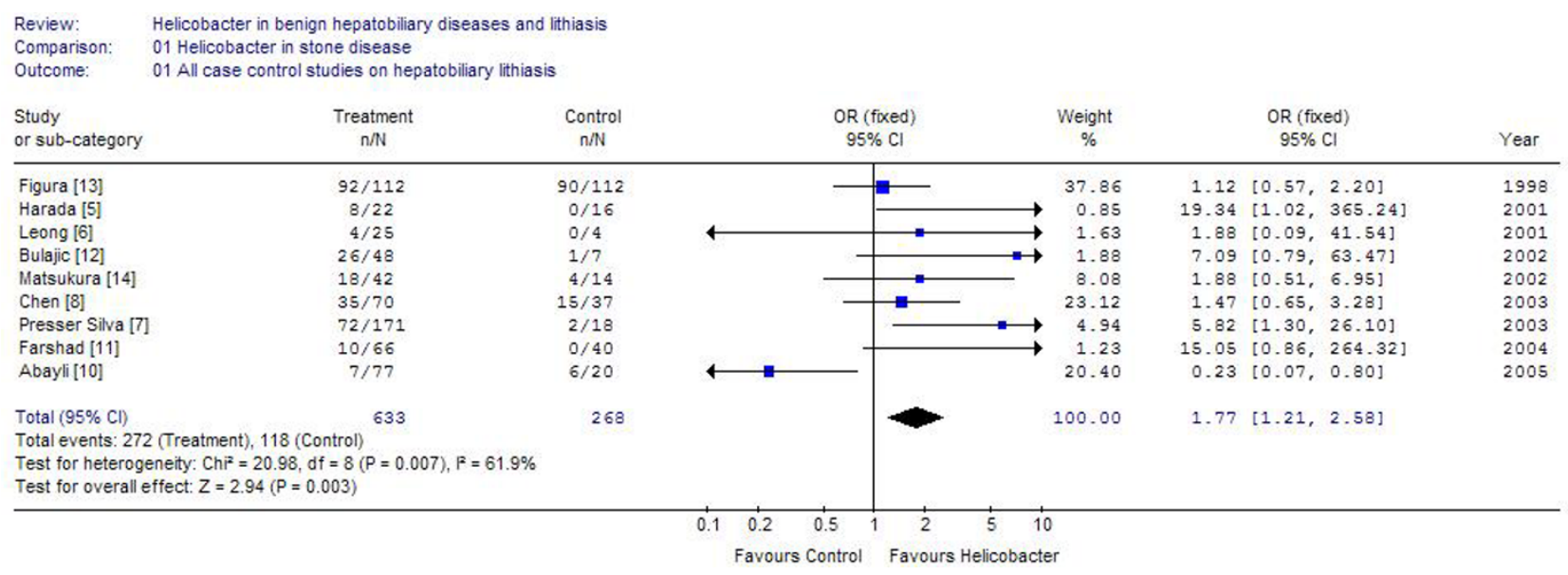

Figure I

Results of Meta analysis of 9 studies on lithiasis patients as cases.

nidus around which the stone may develop or it may produce hydrolyzing enzymes or neucleating proteins like immunoglobulins. CagA protein of Helicobacter has been found to have a homology with aminopeptidase and hence can increase the gallstone formation. Beside these Helicobacter $s p$. Have also been proposed to increase the lithogenicity by production of soluble antigens that may bind to and inhibit key hepatobiliary genes like muc [31]. his may lead to modulation of enterohepatic cycling of conjugated bile acids through genetic regulation of absorption at enterocyte level or modulation of the transit time through gut [31]. Host response to Helicobacter antigens in form of cytokines, and other inflammatory mediators are also proposed to play a role [31]. However, the exact mechanism and exact role played by Helicobacter is still speculated. The results of present meta analysis show 


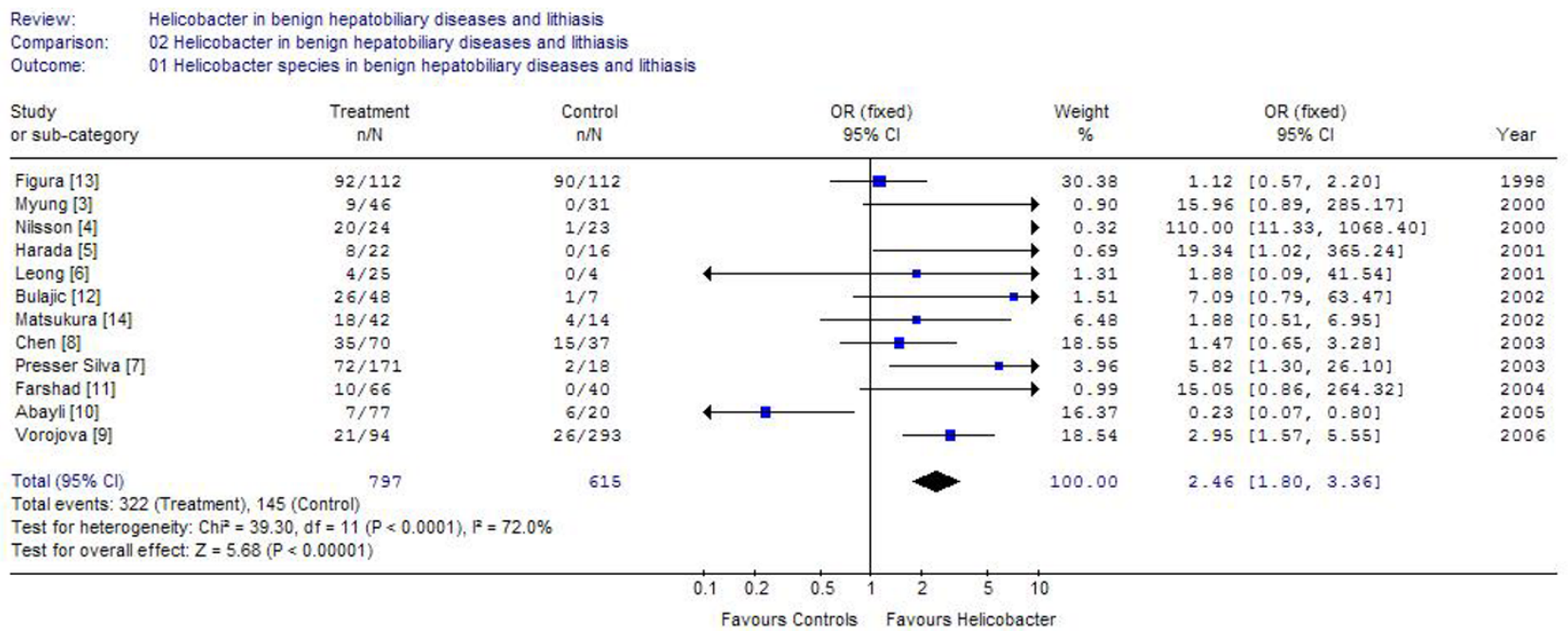

Figure 2

Results of Meta analysis of 12 studies on lithiasis and benign biliary diseases including chronic liver diseases.

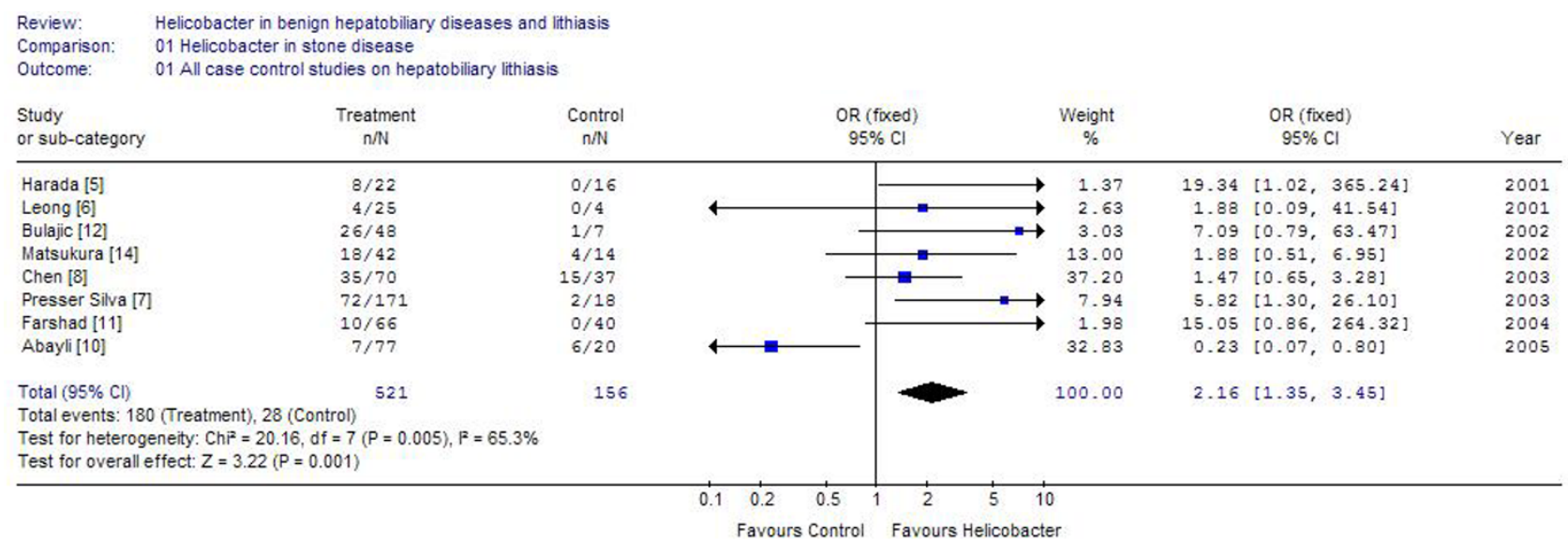

Figure 3

Results of meta analysis of 8 studies on lithiasis after exclusion of study of Figura et al on CAg A protein.

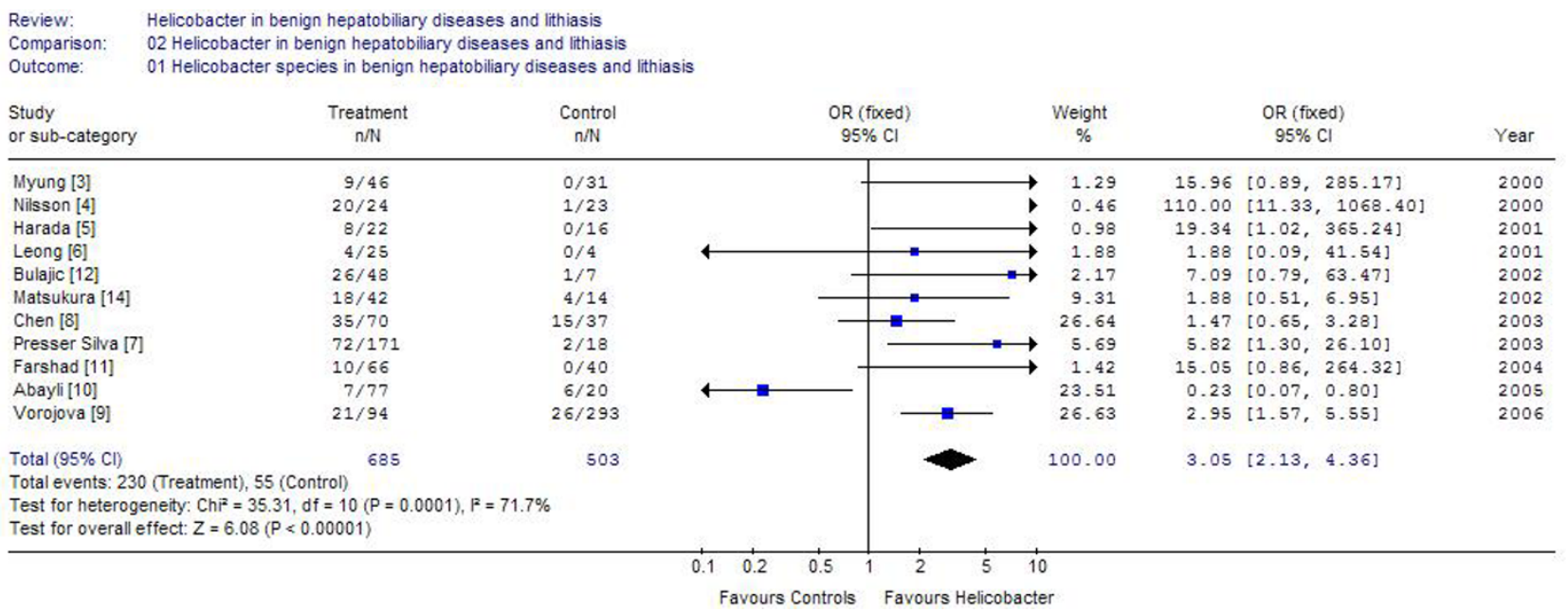

Figure 4

Results of meta analysis of II studies on lithiasis and benign biliary diseases after exclusion of study of Figura et al on CAg A protein. 
a positive association of helicobacter with benign biliary diseases and lithiasis, however further case control studies are needed to further elucidate their relationship.

\section{Conclusion}

The results of meta analysis suggest that the Helicobacter may play a role however due to heterogeneity of the sample and variations in the methodology for detecting Helicobacter these results should be seen with skeptic view and further studies are warranted to definitely answer the question.

\section{Competing interests}

The author(s) declare that they have no competing interests.

\section{Authors' contributions}

MP: Conceived the idea, carried out the literature search, performed the meta analysis and wrote the manuscript.

\section{References}

I. Pradhan SB, Dali S: Relation between gallbladder neoplasm and Helicobacter hepaticus infection. Kathmandu Univ Med J 2004, 2(4):33I-335

2. Neri V, Margiotta M, de Francesco V, Ambrosi A, Valle ND, Fersini A, Tartaglia N, Minenna MF, Ricciardelli C, Giorgio F, Panella C, lerardi E: DNA sequences and proteic antigens of $H$. pylori in cholecystic bile and tissue of patients with gallstones. Aliment Pharmacol Ther 2005, 22:7I5-720.

3. Myung SI, Kim MH, Shin KN, Kim YS, Kim EO, Kim HJ, Park ET, Yoo KS, Lim BC, Seo DW, Lee SK, Min YI, Kim JY: Detection of Helicobacter pylori DNA in human biliary tree and its association with hepatolithiasis. Dig Dis Sci 2000, 45:|405-I4II2.

4. Nilsson HO, Mulchandani R, Trenberg KG, Stenram U, Wadstrom T: Helicobacter species identified in liver from patients with cholangiocarcinoma and hepatocellular carcinoma. Gastroentrol 2000, I20(I):323-324.

5. Harada K, Ozaki S, Kono N, Tsuneyama K, Katayanagi K, Hiramatsu $\mathrm{K}$, Nakanuma Y: Frequent molecular identification of Campylobacter but not Helicobacter genus in bile and biliary epithelium in hepatolithiasis. J Pathol 2001, 193:218-223.

6. Leong RW, Chan MC, Leung WK, Ling TK, Marshall BJ, Sung J]: Detection of Proteobacter and Helicobacter species in bile and association with hepatobiliary diseases. J Gastroentrol Hepatol 200I, I6(suppl):A 35 [Abst].

7. Presser Silva C, Pereira-lima JC, Oliveira AG, Guerra JB, Marques DL, Sarmanho L, Cabral MM, Queiroz DM: Association of the presence of Helicobacter in gallbladder tissue with cholelithiasis and cholecystitis. J Clin Microbiol 2003, 41:5615-56I8.

8. Chen W, Li D, Cannan RJ, Stubbs RS: Common presence of Helicobacter DNA in the gallbladder of patients with gallstone diseases and controls. Dig Liver Dis 2003, 35:237-243.

9. Vorobjova T, Nilsson I, Terjajev S, Granholm M, Lyyra M, Porkka T, Prükk T, Salupere R, Maaroos HI, Wadström T, Uibo R: Serum antibodies to entrohepatic Helicobacter spp. in patients with chronic liver diseases and in a population with high prevalence of $\boldsymbol{H}$. pylori infection. Dig Liver Dis 2006, 38: I7I-176.

10. Abayli B, Colakoglu S, Serin M, Erdogan S, Isiksal YF, Tuncer I, Koksal $\mathrm{F}$, Demiryurek $\mathrm{H}$ : Helicobacter pylori in the etiology of cholesterol gallstones. J Clin Gastroentrol 2005, 39: I34-I37.

II. Farshad Sh, Alborzi A, Malek Hosseini SA, Oboodi B, Rasouli M, Japoni A, Nasiri J: Identifiction of Helicobacter pylori DNA in Iranian patients with gallstones. Epidemiol Infect 2004, 132:1 185-1189.

12. Matsukura N, Yokomuro S, Yamada S, Tajiri T, Sundo T, Hadama T, Kamiya S, Naito Z, Fox JG: Association between Helicobacter bilis in bile and biliary treat malignancies: $H$. bilis in bile from
Japanese and Thai patients with benign and malignant diseases in the biliary tract. Jpn J Cancer Res 2002, 93:842-847.

13. Bulajic M, Stimec B, Milicevic M, Loehr M, Mueller P, Boricic I, Kovacevic N, Bulajic M: Modalities of testing Helicobacter pylori in patients with nonmalignant bile duct diseases. World $j$ Gastroenterol 2002, 8:30I-304.

14. Figura N, Cetta F, Angelico M, Montalto G, Cetta D, Pacenti L, Vindigni C, Vaira D, Festuccia F, De Santis A, Rattan G, Giannace R, Campagna S, Gennari C: Most Helicobacter pylori-infected patients have specific antibodies, and some also have $H$. pylori antigens and genomic material in bile: is it a risk factor for gallstone formation? Dig Dis Sci 1998, 43:854-862.

15. Franklin CL, Beckwith CS, Livingston RS, Riley LK, Gibson SV, BeschWilliford CL, Hook RR Jr: Isolation of a novel Helicobacter species, Helicobacter cholecystus Sp. nov., from gallbladder of Syrian Hamsters with cholangiofibrosis and centrilobular Pancreatitis. J Clin Microbiol 1996, 34:2952-2958.

16. Marshall BJ: Campylobacter pylori : its link to gastritis and peptic ulcer disease. Rev Infect Dis 1990, 157:465-47I.

17. Marshall BJ, Warren JR: Unidentified curved bacilli in the stomach of patients with gastritis and peptic ulceration. Lancet 1984, i: $|3| 1-|3| 4$.

18. Fox JG, Dewhirst FE, Tully JG, Paster BJ, Yan L, Taylor NS, Collins M] Jr, Gorelick PL, Ward JM: Helicobacter sp. nov., a microaerophilic bacterium isolated from bile, liver and intestinal mucosal scrapings from mice. I Clin Microbiol 1994, 32:1238-1245.

19. Avenaud P, Le Bail B, Mayo K, Marais A, Fawaz R, Bioulac-Sage P, Megraud F: Natural history of Helicobacter hepaticus infection in conventional A/J mice, with special reference to liver involvement. Infection Immunity 2003, 71:3667-3672.

20. Wotherspoon AC, Ortiz-Hidalgo C, Falzon MR, Isaacson PG: Helicobacter pylori associated gastritis and primary $\mathrm{B}$-cell gastric lymphoma. Lancet 1991, 338: I 175-1176.

2I. Parsonnet J, Vandersteen D, Goates J, Sibley RK, Pritikin J, Chang Y: Helicobacter pylori infection in intestinal and diffuse-type gastric adenocarcinomas. J Natl Cancer Inst |99|, 83:640-643.

22. Mendall MA, Goggin PM, Molineaux N, Levy J, Toosy T, Strachan D, Camm AJ, Northfield TC: Relation of Helicobacter pylori infection and coronary artery disease. Br Heart J 1994, 71:437-439.

23. Gasbarrini A, Franclschi F, Tartaglione R, Landolfi R, Pola P, Gasbarrini G: Regression of autoimmune thrombocytopenia after eradication of Helicobacter pylori. Lancet 1998, 352:878

24. Di Campli C, Gasbarrini A, Nucera E, Franceschi F, Ojetti $V$, Sanz Torre E, Schiavino D, Pola P, Patriarca G, Gasbarrini G: Beneficial effects of Helicobacter pylori eradication on idiopathic chronic urticaria. Dig Dis Sci 1998, 43:1226-1229.

25. Patel P, Mendall MA, Khulusi S, Northfield TC, Strachan DP: Helicobacter pylori infection in childhood risk facter and effect on growth. BrMed J 1994, 309: I I I9-I I 23.

26. Lin TT, Yeh CT, Wu CS, Liaw YF: Detection and partial sequence analysis of Helicobacter pylori DNA in bile samples. Dig Dis Sci 1995, 40:2214-2219.

27. Fox JG, Floyd ED, Shen Z, Feng Y, Taylor NS, Paster BJ, Ericson RL, Lau CN, Correa P, Araya JC, Roa I: Hepatic Helicobacter sp. identified in bile and gallbladder tissues from Chileans with chronic cholecystitis. Gastroenterology 1998, I I 4:755-763.

28. Fox JG, Yan LL, Dewhirst FE, Paster BJ, Shames B, Murphy JC, Hayward A, Belcher JC, Mendes EN: Helicobacter bilis sp. nov. a novel Helicobacter species isolated from bile, livers and intestines of aged, inbred mice. J Clin Microbiol 1995, 33:445-454

29. Matsukura N, Yokomuro S, Yamada S, Tajiri T, Sundo T, Hadama T, Kamiya S, Naito Z, Fox JG: Association between Helicobacter bilis in bile and biliary treat malignancies: $H$. bilis in bile from Japanese and Thai patients with benign and malignant diseases in the biliary tract. Jpn J Cancer Res 2002, 93:842-847.

30. Fukuda K, Kuroki T, Tajima Y, Fukuda K, Kitajima T, Kuroki T, Onizuka S, Kanematsu T: Comparative analysis of Helicobacter DNAs and biliary pathology in patients with and without hepatobiliary cancers. Carcinogenesis 2002, 23:1927-1931.

31. Maurer KJ, Ihrig MM, Rogers AB, Ng V, Bouchard G, Leonard MR, Carey MC, Fox JG: Identification of cholelithogenic enterohepatic Helicobacter species and their role in murine cholesterol gallstone formation. Gastroenterology 2005, I 28: I023-1033. 